https://doi.org/10.15407/socium2020.03.024

UDC 316.33 .

Benchak O.F., senior-lecturer, department of international studies and public communications, Uzhhorod National University, 89-B, Zankovetska Str., Uzhhorod, 88000, Ukraine, email: olesia.benchak@uzhnu.edu.ua,ORCID iD: https://orcid.org/0000-0001-7498-6077

\title{
CROSS-BORDER INTERACTIONS AS AN OBJECT OF SOCIOLOGICAL RESEARCH: METHODOLOGICAL ASPECTS
}

The unprecedented increase in the intensity of cross-border interactions in the modern world is emphasised, and the necessity of sociological monitoring of these processes is substantiated, the precondition of which is the creation of an appropriate methodology and methods. The stages of formation of theoretical sociology with particular attention to the genesis of cross-border interactions are considered. It is found that the main milestones in the formation of modern methodological principles of sociological analysis of this phenomenon are the post-classical stage of development of theoretical sociology (according to G. Zborovsky's periodisation), the methodology of social constructivism, spatial turn and mobility in social development. The work of J. Urry's sociology of mobility is considered, and its application to the Ukrainian realities is offered. Models of state regulation of cross-border mobility as one of the types of cross-border interactions, defined as the model of "gardener state" and "forest state", are analysed. It is emphasised that these models had an explanatory power concerning the nation-states of the modern industrial era, but in the era of globalisation distort the understanding of central social processes and phenomena. The author analyzed the views of foreign and Ukrainian researchers on the methodological aspects of research on cross-border interactions. The systematic methodology of cross-border research, proposed by $S$. Ustych, is used and proposals for its improvement and implementation in research practices are formulated. The author's position on methodological bases of sociological study of cross-border interactions as a differentiating and solidifying factor is offered.

Keywords: cross-border interactions, stages of development of theoretical sociology, system approach in the research of cross-border interactions.

Бенчак О.Ф., старший викладач кафедри міжнародних студій та суспільних комунікацій, ДВНЗ "Ужгородський наџіональний університет", вул. Заньковеџької, 89-Б, Ужгород, 88000, Україна, email: olesia.benchak@uzhnu.edu.ua, ORCID iD: https://orcid.org/0000-0001-7498-6077

\section{ТРАНСКОРДОННІ ВЗАЕМОДІЇ ЯК ОБ'ЄКТ СОЦІОЛОГІЧНОГО ДОСЛІДЖЕННЯ: МЕТОДОЛОГІЧНІ АСПЕКТИ}

Наголошено на безпрецедентному зростанні інтенсивності транскордонних взаємодій у сучасному світі та обтрунтовано необхідність соиіологічного моніторингу изих процесів, передумовою чого є створення відповідної методології та методики. Розглянуто етапи становлення теоретичної соціології 3 особливою увагою до генези проблематики транскордонних взаємодій. 3'ясовано, щуо основними віхами у формуванні сучасних методологічних приничипів соціологічного аналізу и̧ього явища $\epsilon$ постнекласичний етап розвитку теоретичної соиіології (за періодизацією Г. Зборовського), методологія сочіального конструктивізму, просторовий поворот і поворот соиіальної мобільності (spatial turn ma mobility turn) у розвитку соиіологічного теоретизування. Розглянуто напрацювання сочіології мобільності Дж. Уррі та запропоновано їхню аплікаџію до украӥнських реалій. Проаналізовано

(C) Benchak O.F., 2020 
моделі державного регулювання транскордонної мобільності, як одного з різновидів транскордонних взаємодій, означені як модель “держави-садівника" та “держави-лісничого”. Наголошується, щуо ці моделі мали пояснювальну силу щуодо національних держав епохи індустріального модерну, але в епоху глобалізачії спотворюють розуміння иентральних сочіальних прочесів $і$ феноменів. Здійснено аналіз поглядів зарубіжних та українських дослідників щуодо методологічних аспектів досліджень транскордонних взаємодій. Використано системну методологію транскордонних досліджень, запропоновану С. Устичем, та сформульовано пропозичії щодо ї̈ вдосконалення й імплементації у дослідницькі практики. Запропоновано авторську позицію щчодо методологічних засад соціологічного вивчення транскордонних взаємодій як диференціюючого та солідаризуючого чинника.

Ключові слова: транскордонні взаємодії, етапи розвитку теоретичної соиіології, системний підхід у дослідженні транскордонних взаємодій.

Under the influence of numerous political, economic, technological and sociocultural changes and the associated globalisation and dynamisation of social development in the second half of the last century, the scale, intensity and diversity of cross-border interactions and cross-border mobility, in particular, have increased unprecedentedly. Politicians, managers and scientists are faced with the task of understanding the current preconditions, factors and consequences of cross-border interactions that take place under conditions of complex and somewhat contradictory transformations of state borders. On the one hand, in large part of the world, in particular, in the EU, borders are being weakened, even deinstitutionalised, cross-border cooperation between neighbouring regions of different countries is intensifying, and states are handing over some of their powers to local authorities and NGOs. On the other hand, the issue of borders has come to the forefront of public relations, in particular in the context of events such as Brexit, uncontrolled flow of illegal migrants from conflict zones, exacerbation of terrorism, de facto suspension of Schengen agreements on simplified mobility between EU countries. Measures aimed at overcoming the Covid-19 pandemic, etc. In the case of Ukraine, the interest of scientists and the public in cross-border interactions has become high, primarily in connection with the phenomenon of labour migration. However, even now, there is a lack of unique research by scientists on the outlined issues.

Sociology plays a vital role in understanding the nature and trends of cross-border processes. The purpose of this investigation is to streamline the scientific discourse on cross-border phenomena and the formation of methodological foundations for the study of cross-border interactions as a systemic differentiating and solidifying factor. Since modern sociology is multiparadigmatic and makes extensive use of various methodologies, it makes sense, to begin with, a comparative analysis of general theoretical sociological knowledge complexes and the possibilities of using their axiomatic nuclei in the study of cross-border mobility as the main object of our study.

Cross-border issues from the perspective of periodisations of the development of theoretical sociology. First of all, we apply the periodisation of the genesis of theoretical areas of sociology according to G. Zborovsky with particular attention to the issue of cross-border interactions at different stages of development of sociology [1]. The first, 


\section{Benchak O.F.}

classical, period of theoretical sociology is represented by positivism, Marxism, evolutionism and Weberianism. Sociology, in this period, focuses exclusively on the intra-social level. At this stage, they postulate the unity of humankind (in the study of primitive communities, sociologists, along with anthropologists, find the key to understanding modern societies). However, cross-border phenomena are not actually paid attention. International comparative studies are just emerging. Space itself and its delimitation are not the objects of unique sociological reflection ${ }^{1}$. At the same time, already at this stage, there is an accumulation of empirical data, mapping of economic and social structures in the border regions, there are "laws of migration" by E. Ravenstein, which are the first systematic theoretical interpretations of cross-border interactions.

The neoclassical period is represented by neo-positivism, neo-Marxism, neo-evolutionism, neo-Weberianism, structural functionalism, neo-functionalism, radical-critical theories and theories of conflict. During this period there is a so-called "turn to space" (English - spatial turn) - and accordingly in some sociological areas the problem of the relationship between spatial and social (in particular, the theory of social ecology of the Chicago school). Also, there is a sociological reflection on the processes and structures of the supranational level. Within the framework of ethnosociology, the topic of the formation of state sovereignty, national identities and ethnostereotypes are studied, and issues that were previously analysed only by political science, philosophy, law, and ethics are sociologically studied. In the field of sociology (particularly in the studies of W. Thomas, F. Znanetsky, J. Lindbergh, W. White, etc.) there is the problem of migrant communities in host societies.

The post-classical period is represented by postpositivism, post-Marxism, the theory of systems analysis, the theory of modernisation, the theory of post-industrial society, the theory of globalisation, and others. Sociological theorisations that focus on the supranational level have a significant impact on the general sociological discourse at this stage. In particular, the theory of world-system analysis is spreading (I. Wallerstein, G. Frank), the concept of "world labour market" is included in the scientific circulation, intensive study of migration processes begins, with attention not only to the host countries but also to the countries of origin of migrants. Researchers focus mainly on the asymmetry of migration flows, their relationship to inequality and discrimination, and so on.

The non-classical period is represented by symbolic interactionism, phenomenology, ethnomethodology, and the theory of exchange. At this stage, there is an increasing focus on subjectivity, the spread of quality methods of data collection and interpretation. The study of cross-border interactions in this period is enriched primarily by attention to the daily experience of migrants (in particular, the so-called border crossing studies - the study of border crossing as a special social practice). In 1992, the British researcher L. Malki initiated the formation of a new sociological subdiscipline - the sociology of cross-border movements, which covers the issues of legal and illegal, voluntary and forced border

\footnotetext{
${ }^{1}$ An exception, ahead of its time, in this sense can be called the works of G. Simmel, in particular the work "On the spatial projections of social forms" (1908). He sees the place as a sphere of crystallization of social ties, differences between social groups are revealed, including through the attitude to social space.
} 
crossings in their sociological aspect and includes research on various phenomena of life (from academic mobility to academic mobility) refugees) [2]. Some researchers record in this period a "cultural turn" in the study of migration and cross-border phenomena [3].

The post-classical period, according to G. Zborovsky, is represented by integrative concepts, the theory of communicative action, postmodernism, and feminist sociology. At this stage, theoretical constructions appear, which put the spatial aspect and problems of borders and transboundary phenomena in the centre of the researcher's attention. Within this stage, the study of borders as a social construct, the nature of the reflection of the past and present state of social relations, their role as a social symbol and significance in political discourse. In the key of postmodernism, several researchers have worked out the methodology of "imaginary geography" - discursive formations that simultaneously reflect the socio-political divisions and construct them [4]. During this period, such integrative disciplines as, for example, limology (from the Latin limes - boundaries) are constituted [5]. One of the leading American sociologists A. Portes emphasises the relevance in modern studies of cross-border phenomena such as 1) communities of migrants in host countries; 2) features of new generations of migrants; 3) households, gender and cross-border phenomena; 4) states and migration regimes; 5) international comparisons. He notes that the study of borders shifts from concerns about the formal borders of the state to the study of borders of various socio-spatial and geographical scales, ranging from local and municipal to the global, regional and supranational levels. Such processes, in particular, are reflected in some concepts, in particular - the concepts of "self-elimination of the state", "subsidiarity", "Europe of the regions", etc... The concept of self-elimination of the state (English - state disengagement) implies that states gradually transfer power and responsibility for social management in various spheres, including in the field of cross-border interactions and cooperation, private national and international organisations [6;7]. The concept of subsidiarity provides for the introduction of the political-administrative principle, according to which services to citizens must be provided at the administrative-territorial level, which is closest to them, and this involves the decentralisation of power and full authority to local governments [8]. The concept of Europe of the regions in general consists in the "overflow" of state competencies in favour of the regions, the spread of interregional and cross-border cooperation, management of the regional economy, etc. [9]. At this stage, the border is not seen as a void and a transit zone, but as a place of creation of a new quality of social reality. At the same time, borders not only perform integration functions but also "produce" cross-border phenomena - social groups, practices and identities.

J. Toshchenko calls the most modern direction of sociological theorising constructivism, which is marked by attention to the relationship between macro- and microsociology, objective-subject and subjective-value approach and consideration of the object and subject of sociology in the unity of objective conditions and subjective factors [10]. In the study of cross-border interactions, these methodological principles provide for the understanding of borders, citizenship, group affiliations and other relevant phenomena as social constructs, which both reflect socio-political divisions and construct them (differentiate and integrate the border population, in particular). 


\section{Benchak O.F.}

Cross-border aspects of the sociology of mobility J. Urry. It is at this stage in the development of theoretical sociology that the so-called mobility turn takes place - the second "shift" of theoretical sociology towards the study of transboundary phenomena after the so-called spatial turn. One of the most notable and methodologically innovative and holistic is the contribution to the study of cross-border mobility of the British sociologist J. Urry, who considers mobility a key characteristic of modern society, which determines the existence of communities and blurs the boundaries of territorial sovereignty [11]. The sociology of mobility proposed by the researcher is based on the analysis of movement as a cultural phenomenon, the study of "mobile hybrids" as a collection (English - assemblage) of human and logistical, feelings of the mobility of modern existence. In several works, $\mathrm{J}$. Urry proposes a redefinition of the subject of sociology through the concept of mobility, which allows connecting social relations, processes and interactions, different types of space and time and the material "props" of these processes. Not only people but also numerous objects, images, information are mobile. Physical displacement acquires the meaning of a fundamental act that creates social and is generated by social. There are five key types of mobility: physical movement of people, physical movement of objects, imaginary travel using the media and even conversations, virtual movement using telecommunications technology, as well as moving information using, for example, SMS or email. These categories are not static and closed; they are in constant interaction with each other [12].

J. Urry uses several metaphors to describe various aspects of mobility in the modern world comprehensively. For example, analysing the problem of migration regimes established by nation-states, the researcher emphasises that in the context of globalisation the state loses the role of "gardener" and takes on the role of "forester", who with the help of "hunters" manages mobility and regulates migration of "game". Useful characteristics - in the demographic sense or the sense of educational and professional qualifications) within the territory controlled by it. States are increasingly losing the desire to be the "gardener" of their society, and instead, the desire is growing with the least effort to regulate the movement of their citizens. The "forester state" is interested in having enough "game" at the time of the "hunt". If the "game" becomes small, the "forest state" is ready to breed it, feed it, take care of it, but only until the situation normalises.

As a striking example of "gardening states" J. Urry considers the former socialist states of Eastern Europe, led by the "supergarden" of the USSR. During the Cold War, substantial barriers were built between the countries of the socialist camp and Western countries, which made even cultural communications difficult [13, p. 344]. We emphasise that the example given by the researcher is quite successful. The procedure for obtaining a passport and leaving the Soviet Union was so complicated and lengthy that it in itself discouraged those from leaving, and also drew the attention of the secret services to a potential migrant. The list of documents and permits required for departure usually included: a description of the local branch of the Communist Party (and the description had to be signed by the company's top three - the director, union secretary and party secretary); "Lens" - biographical data with a detailed list of all places of work and residence of those wishing to go abroad; health certificate, in particular, based on a blood test; written justification of the purpose of the trip; invitation (if the trip was private); detailed calendar plan of activities abroad (!); a report on 
the content of the trip, which the citizen submitted to the supervisory authorities after returning from abroad. Having collected the necessary documents, the citizen had to come to the local party cell for an informative interview to instruct the Soviet citizen on the proper behaviour abroad. Along with such a complex and lengthy procedure, there were entire categories of the population who were, in fact, ineligible - workers in the military-industrial complex, politically unreliable citizens, and so on.

At the same time, the role of the gardener is not an invention of the Soviet government. J. Urry writes that the idea of society as a limited and closed system is a consequence of the European idea of nationalism and the nation-state with clearly defined national borders and territory, described, for example, in IG Fichte's "Closed Trade State" (1800). But if the metaphors of the gardener and forester had an explanatory effect on the nation-states of the modern industrial era, in the era of globalisation, the use of these metaphors, Urry writes, only obscures the sociologist's view and prevents him from addressing central social processes and phenomena. Urri proposes to make the central concept of sociology "mobility", which should replace the static and irrelevant concept of "society" [11].

Separate acts of mobility do not occur chaotically but following the capabilities and limitations established by the mobility system - a complex of social relations and material infrastructure that makes a particular type of movement possible, repetitive, predictable, accessible to a wide range of people and includes not only people but also ideas, communications, infrastructure facilities, etc. Any individual movement is possible only as included in the mobility system. The mobility system is a central element of the social order, which regulates all possible social processes.

In mobility studies, J. Urry starts from the basic concept of meeting. Meetings give rise to primary, trust-based social connections that generate network capital. Mobility systems form "habits", repetitive social practices. In the context of cross-border mobility, such social practices that are implemented within transnational social networks are essential [14, p. 156].

Mobility systems are intertwined in stratification processes and in general, in the processes of social differentiation and solidarity, form social inequalities and identities. In itself, mobility and cross-border mobility, as noted by S. Bauman, has reached the very top of the hierarchy of desired values, and freedom of movement (goods that are always lacking and distributed so unevenly) will soon become the main stratifying factor of our late postmodern era [15]. According to the metaphorical definition of J. Urry, (non)access to mobility soon will be the main stratifying factor in the distribution of the world's population on the way to the "gates of heaven and hell". Entrance to paradise depends on access to sufficient network capital, and hell awaits all "network-deprived" in new world order. The researcher connects the low degree of mobility, "local rigidity" with the social periphery of the transnational cultural space, to which people are forced to be "attached", perceive their connection with space as an insurmountable obstacle and rigidly identify with local cultures, and this creates tension in interactions with "others" and threatens conflicts [16]. Immobility is related to those who are excluded from global consumption and global movement or whose displacement is caused by war, poverty or environmental catastrophe [17]. In recent sociology, such conditions are often studied within the framework of the issue of incomplete 
inclusion and exclusion, which are a consequence and at the same time, a manifestation of social inequality.

In the measurement of identities in the age of mobility as a central system-forming phenomenon, the idea of national identity gives way to more universal models of community-related to the concept of universal individual rights legalised by international organisations, codes and laws (including the right to move), environmental rights and others [13, p. 350]. Emphasise that mobility is related to the fulfilment of institutional, group and interpersonal responsibilities. The construction of identity reflects not only the affiliation of the individual to a particular social group, i.e. his status and role affiliation but also his values and life needs [18].

As we can see from the above, both society as a whole and cross-border interactions are mostly studied as systemic phenomena, formations and processes, and this involves the inclusion of methodological sources of one of the general scientific approaches, namely the systemic approach in its modern version. Almost all sociologists agree that individual social phenomena, and specific societies, and humanity as a whole are systems of varying complexity - from simple social systems to complex sociocultural mega-systems, and therefore should be studied taking into account the provisions of the modern post-classical version of the systems approach. Hence the intersection of subject fields of post-nonclassical sociological variations, several methodological turns and a systematic approach in its post-non-classical characteristics. This methodological procedure allows for careful consideration and analysis of cross-border cooperation in the context of increasing mobility of societies and their components.

Cross-border issues in the reflection of Ukrainian sociologists. Sociological studies of cross-border phenomena have become much more active in modern Ukrainian society. Until recently, the Institute of World Economy and International Relations of the National Academy of Sciences of Ukraine worked on the development of problems of cross-border interactions, first of all on its border with the countries of the European Union. The research school of the Institute of Regional Studies of the National Academy of Sciences is widely known. There are significant factual, conceptual and organisational achievements in the study of cross-border phenomena of social life. Well-known experts in this field are V. Prykhodko, I. Artyomov, M. Lendiel, S. Ustych, F. Shandor, N. Ignatol, S. Hobt, G. Shcherba, K. Novosad, N. Varga, H. Prytula, M. Kuryliak and others.

Ukrainian researcher N. Chernysh identified several methodological provisions relating to the sociological study of cross-border interactions [19]. First, as the researcher notes, the sociology of transboundary processes is one of the newest elements of sociological theorising and practice of sociological research. Secondly, the sociological study of transboundary processes is not limited to any one sphere of society or sphere of life. However, it covers virtually all aspects of the existence of an individual, a particular social group, society or humanity as a whole. This lays the foundations for a broad interdisciplinary theoretical, methodological and methodological integration. Third, as a new branch of sociological knowledge, the sociology of cross-border processes intersects in its study of the concept of boundaries of individual societies and thus departs from the traditional understanding of sociology as a science of a particular (separate) society. Note that the 
supranational focus of sociological research, the implementation of cross-national comparative case studies in diversified social contexts (English - multi-sited multinational comparative case studies) are significant for overcoming the so-called methodological nationalism. Fourth, the sociology of transboundary processes is closely related to the sciences of public administration, has a practical orientation and provides for systematic sociological monitoring of transboundary processes.

A detailed sociological interpretation of cross-border interactions was given by the Ukrainian researcher S. Ustych, who dealt with the topic of optimisation of cross-border interactions. According to the methodological positions proposed by the scientist, in the study of cross-border phenomena, it is necessary to take into account the system of heterogeneous factors related to the life of communities of border residents and interactions that cross the state border. In particular, these are socioeconomic, sociocultural and institutional factors, rooted spatially and historically. The system theory of transboundary processes proposed by the researcher consists in taking into account the complex interaction of heterogeneous factors related to the crossing of the state borderline. This approach allows us to distinguish the concept of transboundary processes (transboundary flows) with other established categories that characterise borders and related phenomena [20]. A systematic methodology that provides an analysis of both functional and dynamic characteristics of objects can reveal the complex mechanism of functioning and development of cross-border interactions. Finally, the system methodology has a powerful apparatus of applied development. It can translate the study of cross-border interactions from the category of mainly descriptive to the category of practical [20]. The peculiarities of the system approach in the study of cross-border cooperation are the observance of two cognitive principles: 1) the principle of genetic-functional analysis of the object; 2) the principle of unity of theoretical and methodological and empirical levels of research.

In general, the author shares the research approach of S. Ustych. However, the analysis of the latest transboundary phenomena shows that his systematic understanding of borders and transboundary processes under the current conditions needs to be deepened and modified. In the context of the development of the general theoretical component of modern sociological knowledge, as researchers note, we can consider the concept of S. Ustych intermediate (liminal) between the system-mechanistic picture of the world, on the one hand, and system-physical and system-cybernetic pictures of the world today (more detailed [21, p. 28]). The provisions of his concept correlate well with the current state of development of general sociological theorising in Ukrainian sociology and the need for a better understanding of cross-border processes in the Ukrainian border, as this area of sociological knowledge is still underdeveloped in Ukraine. At the same time, there is a need to expand the conceptual notions of the systemic nature of cross-border interaction, cooperation and mobility. Below we will name the ways of such modification of the system methodology of studying transboundary phenomena proposed by S. Ustych.

The current trend in the scientific understanding of the phenomenon of borders and their transformations under the influence of globalisation, as well as cross-border interactions, is, on the one hand, the institutionalisation of a new integrative discipline of limology and border studies and, on the other hand, the gradual spread of interdisciplinary integration. 


\section{Benchak O.F.}

Among the whole set of various cross-border phenomena, it is expedient to single out those that are part of the subject of sociological research, and thus to speak exclusively of cross-border interactions that occur in a particular social context and space - border. At one time, there was a spatial turn, and mobility turn in the social sciences, so modern studies of cross-border interactions should be based on the recognition of the spatial rootedness of the social reality of the border and the differentiating and solidifying function of borders and cross-border interactions. In addition to distinguishing between micro-, meso-, macro-, and intra-level cross-border interactions, it is advisable to talk about different dimensions of the relevant phenomena - in particular, the institutional-organisational and subjective dimensions. The first one deals with the functioning of formal bureaucratic rules, such as border crossing rules, visa and migration regimes. In the second, we talk about relatively informal interactions between individuals, groups, communities. Both the first and the second occur according to formal-legal, on the one hand, and sociocultural, on the other hand, factors.

The methodological principles of sociological research of transboundary processes, proposed by the author, are as follows: 1) the need to adhere to the cognitive principle of genetic-functional analysis of the object and the principle of unity of theoretical-methodological and empirical levels of research; 2) focus on the practical achievement of the goal, which is to optimise the management of cross-border interactions; 3 ) outlining the range of relevant social actors, organisations, groups and communities and the focus on achieving a particular common good for all parties involved; 4) concentration on the organisational and managerial dimension of cross-border interactions, on the one hand, and on the social context in which organisations operate and managerial innovations are carried out; 5) reliance on a wide range of research methods, primarily sociological, among which traditionally use quantitative and qualitative methods, as well as the latest methods, such as Big Data Analysis; 6) analysis of expert and mass level of perception of cross-border interactions and their organisational support; 7) taking into account two types of consequences of cross-border interactions - changes in the living standards of the local population (recorded through the state of social well-being) and socioeconomic integration of border areas; 8) monitoring nature of research and measurement of both the state and dynamics of the studied transboundary phenomena.

Conclusions. The directions of sociological theorising concerning cross-border mobility as a differentiating and solidifying factor considered in the investigation allow us to draw the following conclusions. Prerequisites for the creation of a modern methodology for studying cross-border interactions are laid down by the following developments in theoretical sociology: post-classical metaparadigm (according to G. Zborovsky's periodisation), which is characterised by the study of borders as a social construct that reflects and constructs socio-political divisions; sociological constructivism, defined by J. Toshchenko as a paradigm marked by attention to the relationship between macro- and microsociology, objective-subject and subjective-value approach and consideration of the object and subject of sociology in the unity of objective conditions and subjective factors; the provisions of the representatives of the so-called "spatial turn" (English - spatial turn) in the social sciences with emphasis on the importance of "space", "place", "maps" (including "imaginary") and 
their impact on social relations; provisions of the theory of sociology of mobility J. Urry (focus on corporate mobility and its indispensability to virtual, the idea of mobility as a privilege).

The analysis of the theoretical understanding of cross-border processes in world and domestic thought made it possible to propose some provisions that concretise and continue the work of sociologists, and that can be used in empirical studies of cross-border interactions.

Perspective directions of research of cross-border interactions are seen first of all in the creation of international research collectives; elaboration and improvement of sociological tools for monitoring the state and dynamics of cross-border interactions; constructing a system of indicators that characterise the factors of micro, meso, macro, and global levels that determine the content of cross-border interactions. The Ukrainian-Hungarian and Ukrainian-Romanian borders as a unique space of social differentiation and integration remain extremely unexplored.

\section{References}

1. Zborovskiy, G. (2008). Metaparadigmal model of theoretical sociology. Socis - Sociological Studies, 4, 3-15 [in Russian]

2. Malkki, L. (1992). National Geographic. The Rooting of Peoples and the Territorialization of National Identity among Scholars and Refugees. Cultural Anthropology, 7, 24-38. https://doi.org/10.1525/ can.1992.7.1.02a00030

3. King, R., Skeldon, R. (2012). Theories and Typologies of Migration: An Overview and a Primer. Malmö: Malmö Institute for Studies of Migration, Diversity and Welfare (MIM).

4. Wolff, L. (1994). Inventing Eastern Europe: The Map of Civilisation on the Mind of the Enlightenment. Stanford: Stanford University Press.

5. Kolosov, V. (2003). Theoretical limology: new approaches. Mezhdunarodnye protsessy - International Trends, 3, 44-59 [in Russian]

6. Security through social cohesion: proposals for a new socioeconomic governance. (2004). Trends in social cohesion, 10. Council of Europe Publishing.

7. Lethbridge, J. (2017, March). Privatisation of migration and refugee services and other forms of state disengagement. Technical Report. Public Services International (PSI). Ferney-Voltaire, France. URL: http://www.world-psi.org/sites/default/files/documents/research/final_psi_epsu_psiru_privatisation_of_ migration_and_refugee_services.pdf

8. Lendiel, M. (2015). Subsidiarity as the principle of social and political organisation: theoretical grounds and Ukrainian perspectives. Visnik Mariupol's'kogo deržavnogo universitetu. Serîa: İstoriâ, politologiâ - Journal of Mariupol State University. Series: History. Political Studies, 12, 211-217 [in Ukrainian]

9. Kurylyak, M. (2018). Evolution of the concept of "Europe of the regions" in the framework of EU regional policy. Ekonomichnyi visnyk Donbasu - Economic Herald of the Donbas, 2 (52), 60-67 [in Ukrainian]

10. Toshchenko, J. (2007). Paradigms, structure and levels of sociological analysis. Socis - Sociological Studies, 9, 6-9 [in Russian]

11. Urry, J. (2012). Sociology Beyond Societies: Mobilities for the Twenty-First Century. London: Routledge. https://doi.org/10.4324/9780203021613

12. Muleev, E.Yu. (2015). "Travel behaviour", "Motility", "Mobility": revisited the conceptualisation of terms. Sotsiologicheskiy Zhurnal - Sociological Journal, 21, 3, 8-28 https://doi.org/10.19181/socjour.2015.21.3.2375 [in Russian] 


\section{Benchak O.F.}

13. Urry, J. (2007). Mobilities. London: Polity.

14. Urry, J. (2011). Climate change and society. London: Polity.

15. Bauman, Z. (1998). Globalisation: The Human Consequences. New York: Columbia University Press.

16. Sizikov, A. (2005). Dynamics of the formation of a transnational cultural space in the context of globalization. Saint Petersburg: Saint Petersburg State University of Culture and Arts [in Russian]

17. Tormosheva, V.S. (2018). Global (im)mobility in the mirror of postmodern transformations: the political aspect. Sotsiologicheskoe obozrenie - Russian Sociological Review, 17, 3, 329-345 [in Russian]

18. Jensen, O. (2010). Erving Goffman and everyday life mobility. In The contemporary Goffman. New York: Routledge. https://doi.org/10.4324/9780203861301

19. Chernysh, N. (2014). Place of sociology of transborder processes in the structure of sociological knowledge. Heopolityka Ukrainy: istoriia i suchasnist - Geopolitics of Ukraine: history and modern times, 2, 20-30. URL: http://nbuv.gov.ua/UJRN/gpuis_2014_2_4 [in Ukrainian]

20. Ustych, S. (2014). Methodology of systematic research of transboundary processes and its social implementation. Uzhhorod: Polygraphy Center "Lira" [in Ukrainian]

21. Chernysh, N. (2019). Ukrainian sociology in search of the general theory in the conditions of interdisciplinarity. Ukr. socium - Ukrainian Society, 2, 9-34. https://doi.org/10.15407/socium2019.02.009 [in Ukrainian]

Received on 06.08.20 and updated on 10.09.20 